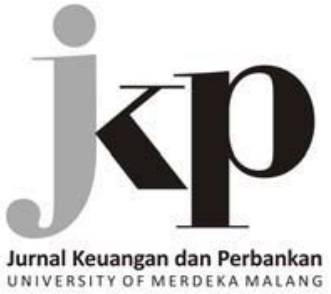

Article history:

Received: 2017-10-11

Revised: 2017-12-09

Accepted: 2018-02-02

Farida Titik Kristanti, Deannes Isynuwardhana Department of Accounting, Faculty of Economics \& Business, Telkom University

Jl. Telekomunikasi, Terusan Buah Batu, Bandung 40257, Indonesia

$\triangle$ Corresponding Author:

Farida TitikKristanti:

Tel/Fax. +62 222011388

E-mail:faridatk@telkomuniversity.ac.id
Farida Titik Kristanti (Indonesia), Deannes Isynuwardhana (Indonesia)

\section{Survival Analysis of Industrial Sectors in Indonesia Companies}

\begin{abstract}
The objective of this study is to discover evidences whether the variables selected as predictors affect the probability of companies experiencing financial distress. Through a purposive sampling technique, 336 companies listed on the Indonesia Stock Exchange were chosen and then grouped into three sectorals groups of companies. One of evidences resulted from survival analysis using cox hazard model showed that if the control of corruption increases then the probability of companies undergoing financial distress will decrease. During the research, the evidence was consistent across the three sectoral groups of Infrastructure, Mining, Property (IMP); Basic industry and chemical, Consumer goods industry, Miscellaneous (BCM); and Agriculture, Trade, and Investment (AT). Results of the study also showed that the companies, on the average, had implemented good corporate governance. It could be seen from the percentage of the independent commissioner involvement, which exceeded the minimum requirement of 30 percent as stated in its regulation. Among the groups, IMP had the highest average of leverage, operational risk, and size, but contrastively it had the lowest average of profitability. The results of this study can be used by the government to further improve the control of corruption in order to prevent companies from experiencing financial distress. Meanwhile, companies should not also do something encouraging bureaucrats to corrupt.
\end{abstract}

Keywords: Corporate Governance; Financial Distress; Financial Performance; Survival Analysis

JEL Classification: G33; G34

Citation: Kristanti, F. T., \& Isynuwardhana D. (2018). Prediction of financial distress of industrial sectors in Indonesian companies using survival analysis. Jurnal Keuangan dan Perbankan, 22(1): 23-36. https:/ / doi.org/10.26905/jkdp.v22i1.1601

\begin{abstract}
Abstrak
Tujuan penelitian ini adalah untuk menemukan bukti apakah variabel-variabel yang terpilih sebagai predictor mempengaruhi likelihood perusahaan mengalami financial distress. Purposive sampling yang digunakan menghasilkan 336 perusahaan dan mengelompokkannya ke dalam 3 kelompok sektor perusahaan yang terdaftar di Bursa Efek Indonesia. Analisis survival dengan cox hazard model yang digunakan menemukan bukti bahwa jika control of corruption naik maka likelihood perusahaan mengalami financial distress akan menurun. Hasil ini konsisten pada ketiga kelompok sektor, yaitu, Infrastructure, Mining, Property (IMP); Basic and chemical industry, Consumer goods industry, Miscelleneous (BCM); dan Agriculture, Trade, and investment (AT). Studi ini juga menemukan fakta bahwa rata-rata perusahaan sudah menerapkan corporate governance dengan baik, yaitu dengan dimilikinya komisaris independen melebihi minimal yang disyaratkan oleh aturan yaitu $30 \%$. Kelompok sektor IMP adalah kelompok yang paling besar rata-rata leverage-nya, operational risk-nya, dan size-nya, namun justru memiliki rata-rata profitabilitas yang paling rendah bila dibandingkan kelompok sektor lainnya. Hasil studi ini bias digunakan oleh pemerintah untuk lebih meningkatkan control of corruption sehingga mampu menghindarkan perusahaan dari kondisi financial distress.
\end{abstract}

Kata Kunci: Financial Distress; Sektor Industri; Analisis Survival 


\section{Jurnal Keuangan dan Perbankan | KEUANGAN}

Vol. 22, No. 1, January 2018: 23-36

Scholars and researchers have studied the phenomenon of bankruptcy and its impact and have tried to formulate models that can predict corporate bankruptcy. Shumway (2001) conducted a comparative study using Altman's Z-sore model and Zmijewski model and applied them using the hazard model. Result of his study showed that apparently almost half (3 of 5) variables used in Altman's modelwere not significant. Then, Shumway proposed a model that used both accounting ratios and market variables for a more accurate prediction of bankruptcy. In addition, he argued that static models (the previous models) were not suitable to predict bankruptcy because the model could only consider a set of explanatory variables for each company and ignored the fact that companiesare changing over time, along with the changes of companiescharacteristics from time to time (Shumway, 2001).

This technique can be used to find out significant factors affecting financial distress in Indonesia so that the probability of survival within certain duration can be identified. The initial identification on potential failures may provide information about company's problems so that the companies can take a turn for abetter decision-making. An early warning system will allow management to take preventive actions against corporate bankruptcy and can also be used to reduce the costs of failures that will arise.

The hazard model, eventually, becomes a bankruptcy prediction model that is often used in various countries such as in USA (Turetsky \& McEwen, 2001; LeClere, 2005; Parker, Peters, \& Turetsky, 2011), UK (Bhattacharjee et al., 2004), Finland (Laitinen, 2005), Australia (Chancharat, 2008; Gepp \& Kumar, 2008), Italy (Donato \& Nieddu, 2014), and China (Bhattacharjee \& Han, 2014).

Researchers have tried many ways to find the selected variables of financial ratio. Altman (1968) eliminated 17 variables and left only 5 variables using the discriminant function to find the best ratio to predict bankruptcy. Other researchers used vari- ous literatures as a basis to find the significant ratio. Several studies are still lacking in theories that result in financial ratio that can be used in the bankruptcy prediction model (Ball et al., 1982). Since there is not any theory that shows the independent variable to be used for the model, this study will use the potential ratio mentioned in previous studies \&data availability as an indicator of financial distress.

The Fisher theory (1993) explained that a company that has a huge debt will start to feel the financial distress when economic recession happens. To be able to pay back the debt, they will have to sell their assets and pull back their deposits. The decrease in their asset value will also decrease the equity of the company and increase the bankruptcy probability. This shows that bankruptcy risk can be predicted by looking at the financial indicators and the equity structure of the company without neglecting the macroeconomic environment. Several studies that usemacro indicators are Platt \& Platt (2002), Nikitin (2003), Bhattacharjee et al. (2004), and Tinoco \& Wilson (2013).

A good financial ratio and a conducive business environment (macro) are not enough to make a company survive. It also needs a good corporate governance. Corporate governance is a phrase that has been a center of attention of economic researchers for the last 2 decades, especially since the increase of bankruptcy in late 1990 (Becht, Bolton, \& Roell, 2002).

This study did not only use financial ratio and corporate governance variables, but also control of corruption variable as a political risk proxy, because in a developing country such as Indonesia, this variable has a huge influence in the business activities. Based on ICRG data (2016), it is shown that the control of corruption variable has been changing to a better status compared to five other political risk indicators. It is started from 0.17 in the period of 2002-2005 and then increase to 0.58 in 2007 and 0.67 in 2008, and it is stagnant at 0.5 in the period of 
2009-2014. With the average of 0.4 in the period of 2002-2014, Indonesia is in a pretty big risk condition.

In accordance with financial criteria, failure can be defined as the insufficiency of cash flow to meet its obligations. These obligations cover liabilities to suppliers and employees including ongoing legal costs, failure in principal and interest repayments on loans (Wruck, 1990). From the perspective of cash flow, Whitaker (1999) has stated that a company is called distress if the company's first year cash flow is lesser than the long-term debt of the company that is due soon. Beaver (1966) explained the financial distress as a major shortage (in corporate finance), which cause the failure of payments on preferred stock dividends and corporate bonds and it causes bankruptcy. Altman (1968) and Ohlson (1980) defined it as a declaration or on the way into bankruptcy. Meanwhile, Opler \& Titman (1994) stated that the distressed industry is an industry whose median sales growth is negative and its median stock returns is smaller than -30 percent.

Definition of corporate governance, according to Claessens \& Yurtoglu (2013), is divided into 2 categories. The first definition focuses on a set of behavioral patterns within the constraints of measurements and another definition concerns on normative frameworks, such as rules by which firms are operated. Claessens \& Yurtoglu considered that the first definition is a logical choice for studies about companies within a country. On the otherhand, the minister decree of state-owned company (Kepmen BUMN) No. KEP-117/M-MBU/2002, said that corporate governance is a process and structure that are used by BUMN organs to elevate the success of the business and the company accountability to result in the value of stakeholders in the long term period while still paying attention to the stakeholders' importance, based on the law and ethics.

In Indonesia, the National Committee on Governance Policy (KNKG) states that Good Corporate Governance (GCG) is needed to encourage markets that are efficient, transparent, and consistent with law and regulations. Therefore, the implementation of GCG needs to be supported by three interconnected pillars, namely state and its executives as regulators, business world as market participant, and society as users of business products and services. GCG principles are transparency, accountability, responsibility, independence, and fairness as well as equity which are needed to achieve sustainability of companies by taking into account the stakeholders. Inside the companies, councils play a very important role. In Indonesia where two tier systems are implemented, boards consist of board of commissioners and board of directors. Board of commissioners is a party that performs a monitoring function on the performance of management, while board of directors is a party that performs the day-to-day operations of the company.

Literatures on corporate governance mechanism as a potential predictor in financial failure elaborate several attributes. Elloumi \& Gueyee (2001) in their study in Canada, used shareholder percentage, ownership concentration by director and block holder, and percentage of director from the outside of the company as well as if the CEO is a member of the board. Abdullah (2006) in Malaysia used board independence, executive director, non-executive director, and outside block holding variables. Fich \& Slezak (2008) in their study in US used board size, outside board, and years CEO variables. In China, Xia-Li, Jun-Wang, \& Ian-Deng (2008) explored the ownership concentration variables (largest, state, ultimate, and balancing degree), auditor opinion and administration expense. Lastly, in Thailand, Polsiri \& Sookhanaphibarn (2009) explored ownership concentration variables above 25 percent, of business rank from the controlling shareholders and boards that are controlling shareholders. This research used independence commissioner, board size, CEO diversity, and ownership concentration. 


\section{Jurnal Keuangan dan Perbankan | KEUANGAN}

Vol. 22, No. 1, January 2018: 23-36

Various studies defined Board Independence as a percentage of independent directors from outside company (Abdullah, 2006). To meet the purpose of this study, the definition of Board Independence was adopted to show the percentage of independent commissioners coming from outside the companies compared to the total commissioners of the companies. By having more independent commissioners the probability of experiencing financial distress is expected to decrease.

Corporate governance researchers argued that gender diversity has the potential to positively affect a company performance. Board members varying in gender can develop activities that can ultimately improve the company performance to avoid financial distress. Along with the purposes of this study and in accordance with Chancharat (2008), director diversity is defined as the percentage of the number of women in a company's board of directors. The CEO as a decision maker will affect the company's operations. By using dummy variables, any company having female CEO will be coded (1) and code (0) as the opposite. With the diversity of $\mathrm{CEO}$, the probability of being the companies experiencing financial distress is expected to decrease.

Concentration of ownership shows the percentage of stock ownership above 20 percent (Chancharat, 2008). If the stock ownership is highly concentrated then the probability of companies that survive will also be high because they can influence the corporate decision making. The higher the stock ownership is concentrated, the lesser the probability of being the companies experiencing financial distress will be.

Financial risk indicates the financial risk faced by companies due to the fixed expense that must be borne by them. According to Parker, Peters, \& Turetsky (2011), the risk is measured by using the ratio of total debt to total assets. The greater the financial risk is, the greater the risk of a company to not be able to meet its obligations is. Therefore, the company will experience financial distress.
Operational risk refers to the risk that indicates how long a company experiencing a worsening performance can survive. The risk is measured by dividing total assets by the company's sales (Parker, Peters, \& Turetsky, 2011). When the risk is getting bigger, assets used by a company will not be able to generate high sales. It means that if the performance of a company is worse, the company may experience financial distress.

Size shows a company's ability to use its assets to survive in bad conditions. In line with the Fich \& Slezak (2008) study, the size of a company will be measured by the natural log of total assets. Therefore, the size will affect the probability of companies experiencing financial distress. The larger the size of the company is, the greater the risk of failure is.

Liquidity shows the short-term cash flow positions which become a direct determinant on a company's ability to survive when the company experiences financial distress. According to Turetsky \& McEwen (2001) and to meet the purpose of this study, the liquidity was measured using the ratio of current assets to current liabilities. There is a trade-off between liquidity and profitability, so when liquidity is high, then profitability will decrease. As the result, the probability of a company to experience financial distress will rise.

Profitability shows the ability of companies to earn profits. This ability will determine whether a company is able to avoid financial distress or not. Based on the study of Ahmad (2013) and the purpose of this study, the profitability then wasgained by comparing net profit after tax (EAT) to total assets. The higher the profitability of the company is, the less likely the company is to experience financial distress.

Market perceptions are used in this study to detect market prospects that cannot be seen only from accounting data. An efficient market will collect all non-financial information that will influence the performance of the company as reflected in the 


\section{Survival Analysis of Industrial Sectors in Indonesia Companies}

Farida Titik Kristanti, Deannes Isynuwardhana

accounting data. By referring to Parker, Peters, \& Turetsky (2011), then the market perception in this study was measured by using the comparison between market value of equity and book value of common equity. The higher the market perception value of the company is, the less likely the company is to experience financial distress.

Political risk indicates the probability of a political event that would alter the prospect of a companies' ability to gain a return on a specific investment (Haendel, 1979). Van-Wyk, Dahmer, \& Custy (2004) stated that political risk refers to government policy and social instability that influencebusiness environment. For the purpose of this study, control of corruption was used as a proxy of the political risk. Haendel (1979) and Van-Wyk, Dahmer, \& Custy (2004), stated that political risk can harm a company and threaten the future of business activities. Glaeser (2012) also explained that the lost welfare can arise from private initiative sources (corruption) and it is purely political favoritism. If a political leader has a potential to corrupt, then the public ownership will be the party to bear the consequences. Corruption will lead to the absence of rules that ultimately make the cost of a company increase which also leads to the increase of selling price. Therefore, corruption can reduce the ability of the company to earn profits. The greater the control of corruption is, the less likely the company is to experience financial distress.

The study of Cashman, Harrison, \& Sheng's (2014) on the property market in Asia Pacific showed that political risk improvement (using corruption index from Transparency International) also increases cost of equity and weighted average cost of capital of a company. Sandstrom (2008) in his study in Finland used ICRG as a political risk indicator that resulted in positive influence to the debt default probability. The study of Voelker et al. (2008) on perceptions of political risks in the Indonesian Power project identified that political risks in Indonesia are relatively high. The data used in their study was taken from the International Country Risk Guide Methodology (ICRG) of the Political Risk Service Group (PRS) that covers 140 countries and has existed since 1984.

This study is a continuation of the previous studies. It predicts bankruptcy in Indonesia through survival analysis using cox hazard model and time dependent covariates (Kristanti et al., 2016; Kristanti \& Effendy, 2017; Kristanti \& Herwany, 2017). However, in this study, the authors wanted to apply the analysis in sectors whose companies listed on the Indonesia Stock Exchange (IDX). This study is expected to contribute to the development of financial management science. Besides, results of this study is expected to fill the knowledge of financial distress and survival model for industrial sectors in Indonesia. The results showed that each sectoral group produces a different model but all groups indicate consistent results showing that control of corruption is a significant determinant in influencing the probability of companies to experience financial distress.

\section{METHODS}

This research composed a bankruptcy prediction model for several sectoral groups of companies listed on the IDX. Considering the proximity in the type of activity, those companies were categorized into 3 major sectoral groups, which are: (1) infrastructure, property, and mining sectors; (2) basic industry \& chemical, consumer goods industry, and miscellaneous sectors; and (3) trade, service \& investments, and agriculture sectors. The survival analysis technique was used with attributes predictors of corporate governance, financial ratios, and political risk that are based on data.

Company data in large quantities of more than 10 years which were listed on the IDX was used in this study. The study expects that by using all sectors listed on the IDX it will improve the effectiveness of financial distress prediction models to 


\section{Jurnal Keuangan dan Perbankan | KEUANGAN}

Vol. 22, No. 1, January 2018: 23-36

be used by companies in Indonesia because the samples may represent the overall economic condition of Indonesia.

This study used purposive random sampling in which samples should be non-financial companies and they must have completed data during the study period of 2002-2015. Of 537 companies recorded until 2016, 336 samples were chosen.

This survival analysis incorporated failure time as a dependent variable in the model. So the dependent variable in this research is the duration of an event. Time can be year, month, week, or day that is started from the beginning of the study until an event occurs. According to Kleinbaum \& Klein (2012), event is an experience that is designed and may occur in individuals. In this study, time to event refers to the number of years started from the first year a company is listed on the stock until the year the company experiences an event of financial distress. Distressed companies are companies with negative equity. It is in line with the definition stated by Beaver (1966) and Andrade \& Kaplan (1998) who defined a distressed company as a company having an inability to pay its obligations. The time of the company's failure is stated in year. If a company has negative equity, then it is stated by 1 , whereas if it has positive equity, it is expressed by 0 .

The situation in the survival analysis can be depicted in Figure 1. $\mathrm{X}$ is a sign that the company experiences an event or financial distress. Company A is a company that had been observed since the beginning of the study until it experienced an event in the $5^{\text {th }}$ year. Company $B$ was included into the study in the $3^{\text {rd }}$ year but it experienced distress in the $6^{\text {th }}$ year. Company $C$ had been observed for 6 years but during the study it did not experience distress. The situation is called censored data (censoring). Company D joined in the $4^{\text {th }}$ year of the study and experienced distress in the $10^{\text {th }}$ year. Meanwhile company E joined the study in year 8 and experienced distress in the $11^{\text {th }}$ year.

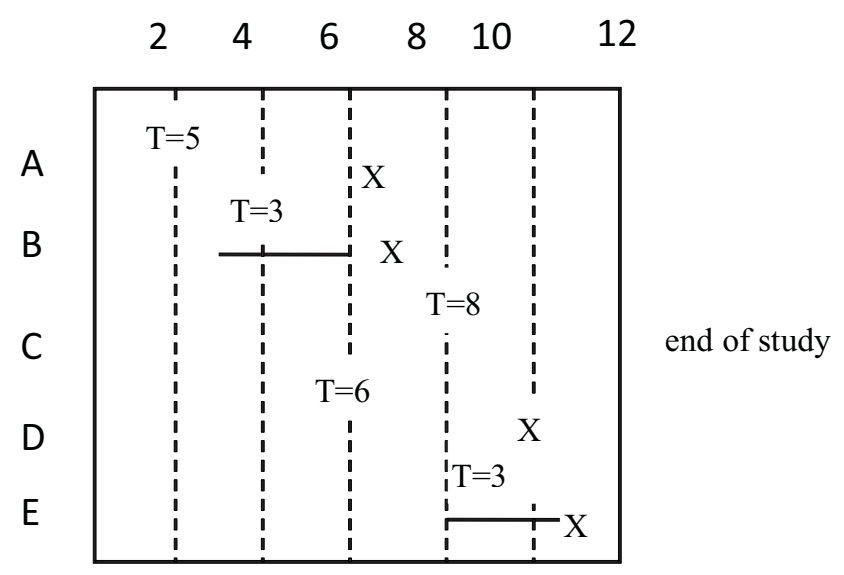

Figure 1. Examples of Companies Experiencing Events (Financial Distress)

According to Shumway (2001), we can exploit the company's time-series data by incorporating annual observations as time-varying covariates. Zhou, Kim, \& Ma (2012) referring to LeClere (2000) illustrated the followings, if an individual experiences an event in the $8^{\text {th }}$ period, then there will be 8 observations to make an estimate. Seven observations having a variable bound to code 0 (zero) and one observation, on the time when the event occurs, is tied to code 1 . After the $8^{\text {th }}$ period, no observations can be taken for the individual because it has experienced the event and is no longer at that risk. Therefore, Table 1 can be constructed from the Figure 1. Table 1 shows the data of time failure with time-varying covariates. $X_{\mathrm{A} 1.1}$ describes covariates $X_{1}$ for the company $A$ in the $1^{\text {st }}$ year. Meanwhile $X_{\mathrm{A} 2.1}$ shows covariate $X_{2}$ for company $A$ in the $1^{\text {st }}$ year and it is applied to the company B and C.

Explanatory variables used in this study were corporate governance, financial ratios, and political risk. Corporate governance variables included independent commissioner, gender diversity, and concentration ownership, while financial variables consisted of financial risk, operating risk, size, liquidity risk, profitability, and market perception. 
Table 1. The Examples of Time Failure with Time-Varying Covariates

\begin{tabular}{|c|c|c|c|c|c|c|}
\hline \multirow[t]{2}{*}{ Company } & \multirow[t]{2}{*}{ Time } & \multirow[t]{2}{*}{$\begin{array}{c}\text { Failed (1) } \\
\text { Censored (0) } \\
\end{array}$} & \multicolumn{4}{|c|}{ Explanatory Variables } \\
\hline & & & $\mathrm{X}_{1}$ & $\mathrm{X}_{2}$ & …….................. & $X_{p}$ \\
\hline A & 5 & 1 & $\mathrm{X}_{\mathrm{A} 1.5}$ & $\mathrm{X}_{\mathrm{A} 2.5}$ & & $\mathrm{X}_{\mathrm{Ap} .5}$ \\
\hline B & 3 & 1 & $\mathrm{X}_{\mathrm{B} 1.6}$ & $X_{B 2.6}$ & .......................... & $X_{\text {Bp. } 6}$ \\
\hline C & 12 & 0 & $\mathrm{X}_{\mathrm{C} 1.12}$ & $\mathrm{X}_{\mathrm{C} 2.12}$ & …....................... & $\mathrm{X}_{\mathrm{Cp} .12}$ \\
\hline D & 6 & 1 & $\mathrm{X}_{\mathrm{D} 1.10}$ & $\mathrm{X}_{\mathrm{D} 2.10}$ & & $\mathrm{X}_{\mathrm{Dp} .10}$ \\
\hline E & 3 & 1 & $\mathrm{X}_{\mathrm{E} 1.11}$ & $\mathrm{X}_{\mathrm{E} 2.11}$ & & $X_{E p .11}$ \\
\hline
\end{tabular}

Time varying variables are explanatory variables that change over time. The financial ratios, corporate governance, and political risk used in this study belong to time-varying variables because they changed in value throughout the study period. Cox Hazard Model with time-dependent covariates can be shown by the following equation:

$$
\mathrm{h}_{\mathrm{i}}\left(\mathrm{t} \mathrm{Iz}(\mathrm{t})=\mathrm{h}_{0}(\mathrm{t}) \cdot \exp \quad \sum_{\mathrm{j}=1}^{\mathrm{p}}(\beta \mathrm{jZij}(\mathrm{t})\right.
$$

Where:

$h_{i}(t z(t)$ : the function of time-dependent hazard of (i) company at time ( $t$ )

$z_{i j}(t) \quad$ : the value of year $(j)$ covariate at time $(t)$ of (i) company, âjis the coefficient of $z_{i j}$

ho(t) : the baseline hazard that illustrates the effect of hazard duration in the absence of covariates.

Therefore, hazard at time $t$ depends on the value of the predictor variable at time $t$. To process data of the study the program of SPSS (Cox Regression, time dependent) was used.

The Cox Proportional Hazard Model is a semi-parametric model for survival analysis, which is very widely used. Kleinbaum \& Klein (2012) stated that The Cox Proportional Hazard Model (CPHM) is popular because it is a robust model that will result in closely approximate results. The proportional hazard model is presented as follows: $\mathrm{h}_{\mathrm{i}}(\mathrm{t})=\mathrm{h}_{0}(\mathrm{t}) \exp \left(\mathrm{X}_{1}, \square\right)$

$h_{i}(t)$ is an arbitrary unspecified baseline hazard rate that measures the effect of time on a hazard level for an individual whose variable has a zero value. $X$ represents the vector of the variable affecting hazard and $b$ is the vector of the coefficient. There is a deficiency in the specificity of the baseline hazard function that forms the semi-parametric model or free of distribution (Chancharat, 2008).

The hazard model containing the exponential element as stated in formula 3 can be changed into a $\log$ form. The Regression Model can be written as follows:

$\log h_{i}(t)=\alpha(t)+\beta_{1} X_{i}(t)+\beta_{2} X_{i}(t)+\beta_{3} X_{i}(t)+$

Finally The Cox proportional hazard model was used to assess the relationship between the explanatory variable and survival time and to evaluate the probability of survival within a given time frame. The model is shown as follows:

$\log h_{i}(t)=\alpha(t)+\beta_{1} I_{i}(t)+\beta_{2} \operatorname{GENDIV}_{i}(t)+\beta_{3} \operatorname{CONOWN}_{i}(t)+$ $\beta_{4} \mathrm{FR}_{\mathrm{i}}(\mathrm{t})+\beta_{5} \mathrm{OPRISK}_{\mathrm{i}}(\mathrm{t})+\beta_{6} \mathrm{SZ}_{\mathrm{i}}(\mathrm{t})+\beta_{7} \mathrm{LIQ}_{\mathrm{i}}(\mathrm{t})+\beta_{\square} \mathrm{PROFT}_{\mathrm{i}}(\mathrm{t})+$ $\beta_{9} \mathrm{MP}_{\mathrm{i}}(\mathrm{t})+\beta_{10} \mathrm{PR}_{\mathrm{i}}(\mathrm{t})$

Where:

$h_{i}(t) \quad:$ hazard of $i$ company entered in financial distress at time $t$ (hazard at time $t$ depends on the value of each time of t) 


\section{Jurnal Keuangan dan Perbankan | KEUANGAN}

Vol. 22, No. 1, January 2018: 23-36

$\alpha(t)$

$: \log h_{0}(t)$, where $h_{0}(t)=$ hazard function for an individual having value 0 for all variables

INDPCOM : independence comissioner

BDIV : board diversity

CEODIV : CEO diversity

CONOWN : concentration ownership

FR : financial risk

OR : operating risk

SZ : size

LIQ : liquidity

PROFT : profitability

MP : market perception

PR : political risk

Independence commissioner shows the percentage of the commissioner who are from the outside of the company that then was compared to the total commissioner in the company. The better the function of the independent commissioner in supervising the managers is, the bigger the increase of the supervision of the direction in the financial policy or cost management that will result in a loss for the company and lead to a financial difficulty that can be minimalized will be. Board diversity is defined as the percentage of female in a board of a company. Female directors are expected to reflect a good sight to the clients \& employees, and lead to increase the performance of the company and decrease the probability of the financial distress. CEO diversity is defined as the existence of female as a CEO of a company (Kristanti, 2015). By using a dummy variable, if there is any company whose CEO is female, it will be marked (1), and for those whose CEO are not female it will be marked (0). Companies with female top executives are expected to have better performance, so that the financial distress probability will decrease. Ownership concentration shows how big a percentage ofthe shareholders above 20 percent (Chancharat, 2008). Because those are related to the bigger shareholder concentration, the company is expected not to experience financial distress.

Financial risk shows financial risks that are being faced by a company due to the burden it takes. Parker, Peters, \& Turetsky (2011) said that this risk is being calculated by several total debt ratios to the total assets. When leverage increases, the risk also increases. Therefore, the financial distress is predicted to increase as well. Operating risk shows the risk indicating how long a company will survive when its performance is worsening. This risk is calculated by dividing total asset by sale (Parker, Peters, \& Turetsky, 2011). The probability of bankruptcy is expected to decrease when the ratio of assets to sale decreases. Size shows the capability of a company to utilize the assets to survive in a bad condition. Fich \& Slezak (2008) explained that size is calculated by the natural log total asset. Bankruptcy probability will increaseas the company size increases. Liquidity shows the short term cash flow that is a direct determinant to the survival capability of a company when financial distress occurs. Based on Turetsky \& McEwen (2001), for the goal of this study, liquidity was calculated using the ratio of current asset and current liability. Most companies will be illiquid and finally have financial insolvency that lead to bankruptcy. So, there is a negative impact between company liquidity and financial distress probability. Profitability is a ratio between EAT and total asset. When EAT is high, the company is likely to be able to pay all their liabilities so it is likely to be spared from the financial distress condition. Market perception was used in this study to see the market prospect that cannot be seen only from accounting data. Based on Parker, Peters, \& Turetsky (2011), this study measured market perception by using the ratio of market value of equity with book value of common equity. Political risk shows the probability of the political occurrences that could change the capability prospect of a com- 
pany to earn profit of the certain investment (Haendel, 1979). In this study, control of corruption was used as a political risk proxy. Data used ICRG methodology from PRS group that measures political risk index.

The hazard ratio can be seen from $\mathrm{e}^{\mathrm{Bj}}$ indicating the effect of the change of an independent variableon its hazard function (ht) or distress probability. The hazard ratio of 1 indicates that the change of one unit of independent variable has no effect on the probability of company's distress when another variable is considered constant. The hazard ratio that is smaller (high) than 1 indicates the probability of lower (high) company distress. Each independent variable coefficient (bj) estimates the hazard rate change of a particular independent variable.

\section{DISCUSSION}

The results of data collection showed that with 336 samples in the study period of 2002-2015, only 61 companies experienced financial distress, while 275 companies did not experience financial distress (Table 2). The highest number of companies experiencing financial distress was obtained in 2002 as many as 27 companies. It is assumed as the impact of the 1998 crisis. However, in the subsequent years, the numbers relatively declined. Therefore, it describes the better management of the company and the good economic condition of Indonesia.
Table 2. Number of Companies Experiencing Financial Distress and Vice Versa

\begin{tabular}{cc}
\hline \multicolumn{1}{c}{ Periode } & $\begin{array}{c}\text { Number of } \\
\text { Companies }\end{array}$ \\
\hline $\begin{array}{l}\text { Number of companies experiencing } \\
\text { financial distress 2002-2015 }\end{array}$ & 275 \\
Number of companies that is not \\
experiencing financial distress \\
2002-2015 & 61 \\
- 2002 & \\
- 2003 & \\
- 2004 & 27 \\
- 2005 & 5 \\
- 2006 & 1 \\
- 2007 & 4 \\
- 2008 & 6 \\
- 2009 & 2 \\
- 2010 & 1 \\
- 2011 & 1 \\
- 2012 & 4 \\
- 2013 & 1 \\
- 2014 & 1 \\
- 2015 & 4 \\
\hline
\end{tabular}

Its significance can be seen from the goodness of fit value using Chi-square which is calculated as log-likelihood function. If the Chi-square value is significant then the null hypothesis is rejected and it assumes that the explanatory variable has a significant relationship to the survival time. Table 3 shows that all have probabilities smaller than 1 percent. It means that Chi-square value is significant at alpha 1 percent and the null hypothesis is rejected. It implies that there is a significant influence of the explanatory variable on its survival time and fit model.

Table 3. Coefisien of Omnibus Test of Model

\begin{tabular}{lccc}
\hline & -2 Log Likelihood & Chi-square & Sig \\
\hline Infrastructure, Mining \& property (IMP) & 114.135 & 76.484 & .000 \\
$\begin{array}{l}\text { Basic industry \& chemicals, Consumer goods } \\
\begin{array}{l}\text { industry, dan Miscellaneous (BCM) } \\
\text { Agriculture dan Trade, service \& Investments (AT) }\end{array}\end{array}$ & 162.993 & 102.613 & .000 \\
\hline
\end{tabular}


Table 4. Statistical Test of Analysis Survival Used Time Varying Covariates

\begin{tabular}{|c|c|c|c|c|c|c|c|}
\hline \multirow[t]{2}{*}{ Variabel } & \multirow[t]{2}{*}{$\begin{array}{l}\text { Expected } \\
\text { Ratio }\end{array}$} & \multicolumn{2}{|c|}{$\begin{array}{l}\text { Infrastructure, Mining, } \\
\text { and property (IMP) }\end{array}$} & \multicolumn{2}{|c|}{$\begin{array}{l}\text { Basic industry \& chemicals, } \\
\text { Consumer goods industry, } \\
\text { and Miscellaneous (BCM) }\end{array}$} & \multicolumn{2}{|c|}{$\begin{array}{c}\text { Agriculture \& Trade, service, } \\
\text { and Investments (AT) }\end{array}$} \\
\hline & & Sig & $\operatorname{Exp}(B)$ & Sig & $\operatorname{Exp}(B)$ & Sig & $\operatorname{Exp}(\mathrm{B})$ \\
\hline IC & $<1$ & 0.009 & $0.000^{* * *}$ & 0.287 & 0.157 & 0.211 & 394.273 \\
\hline GDIV & $<1$ & 0.667 & 2.371 & 0.700 & 1.658 & 0.433 & 42.999 \\
\hline COWN & $<1$ & 0.203 & 0.312 & 0.424 & 2.304 & 0.962 & 2530.797 \\
\hline FR & $>1$ & 0.010 & $2.539 * *$ & 0.468 & 1.230 & 0.346 & 154.629 \\
\hline OPRISK & $>1$ & 0.741 & 1.102 & 0.738 & 1.041 & 0.044 & $2.501^{* *}$ \\
\hline SZ & $<1$ & 0.017 & $0.418^{* *}$ & 0.411 & 0.724 & 0.004 & $7.140^{* *}$ \\
\hline LIQ & $<1$ & 0.880 & 1.101 & 0.389 & 1.099 & 0.734 & 1.358 \\
\hline PROFT & $<1$ & 0.008 & $0.002^{* * *}$ & 0.158 & 0.002 & 0.865 & 0.000 \\
\hline MP & $>1$ & 0.350 & 0.836 & 0.450 & 1.997 & 0.974 & 47039.195 \\
\hline PR & $<1$ & 0.000 & $0.000^{* * *}$ & 0.000 & $0.000^{* * *}$ & 0.000 & $0.000^{* * *}$ \\
\hline T-COV & & 0.120 & 0.988 & 0.859 & 1.003 & 0.138 & 0.768 \\
\hline
\end{tabular}

Source: Estimation Results

${ }^{* * *}$ ) significant at alpha 1 percent, ${ }^{* *}$ ) significant at alpha 5 percent, $\left.{ }^{*}\right)$ significant at alpha 10 percent

The estimation result using cox proportion hazard model with time varying model is shown in Table 4.

Table 4 shows that based on the statistical test of the 3 sectoral groups, only political risk variable with consistent control of corruption indicator has a significant influence ( $\alpha=1$ percent) on the probability of being companies experiencing financial distress. Control of corruption has a significant negative effect on the probability of survival. If the control of corruption rises, then the probability of survival will decrease, and vice versa. It is very useful for government as the party directly related to the control of corruption because government has a duty to do it. It signifies that the government should further improve the control of corruption in order to reduce the probability of companies experiencing financial distress. Corruption is not only related to one party, namely the bureaucrat, but it also related to paying parties, i.e. companies. Then the companies should also refrain from being the party to initiate the unauthorized payment. If both parties obey it then undoubtedly the culture of corruption can be vanished and it will not burden companies which ultimately lead to a high-cost economy.
An interesting thing from the IMP sectoral group is that financial risk measured by firm leverage shows a significant positive result $(a=5$ percent) on the probability of companies experiencing financial distress that is in line with Antikasari \& Djuminah (2017). It means that the higher the leverage is, the higher the company's financial distress will be. It does not occur in two other sectoral groups. It is known that this sectoral group has an average debt of 62.8 percent which indicates that this group of companies has more debt than its own capital and indicates a high risk in this group. Similarly, when it is compared to other sector groups, namely BCM and AT, the averages of both groups are 53.4 percent and 50.5 percent.

In the IMP sector, profitability measured by ROA also shows a significant negative result of 1 percent. It means that the greater the company's profits are, the financial distress will decline. With an average ROA of 0.8 percent, this sector has a smaller profitability than BCM and AT groups whose percentages gained 1.7 percent and 2.8 percent respectively.

Independent commissioner, in the IMP sector, has a negative effect on the company's financial 


\section{Survival Analysis of Industrial Sectors in Indonesia Companies}

Farida Titik Kristanti, Deannes Isynuwardhana

distress. More independent commissioners in a company will decrease the probability of being the company experiencing financial distress. The average of IC in this sector is 42.5 percent. It is higher than in AT group of 40.9 percent and the BCM group of 39.7 percent. It indicates that the IMP sector having more independent commissioners is capable of supervising companies well so that the companies can avoid financial distress. This percentage is in accordance with the regulation of Capital Market Supervisory Agency (Bapepam) No. I-A concerning the General Regulation of Equity Securities Listing. It is for the sake of good corporate governance. The regulation stipulates the number of independent commissioner that should be accountedat least 30 percent of the total commissioners.

Meanwhile, an interesting thing coming from the sector of agricultural and trade, service and investments is its operational risk that was measured by dividing total assets by sales. It showed a significant positive result at alpha 5 percent. It explains that the higher the operational risk is, the higher the company's financial distress will be. The average operational risk in this sector is 3.33. It is greater than the BCM sector of 2.05, but it is smaller than the IMP group of 4.73. It indicates that the ability of assets to generate sales in the AT sector is relatively moderate.

Size has a significant negative effect on alpha of 5 percent in both the IMP and AT sectors that is not inline with Pujiastuti \& Yuharningsih (2014) and Kristanti (2014). It implies that the higher the size of the company is, the smaller the probability of companies experiencing financial distress will be. It means that the larger the companies are, the bigger their ability to manage their companies better is, and so they can avoid financial distress. In addition, larger companies generally have ability to get external financing easier than small companies. The size of the IMP sector is 6.54, while the AT sector is 6.23. Meanwhile, the opposite occurs in the AT sector group, the size turned out to have a positive effect on financial distress company. The bigger the size of the company is, the higher their financial distress will be.

This study reinforces previous studies that have been done by the authors using control of corruption as a variable that consistently affects the company's financial distress with a negative direction. This means that the greater the control of corruption is, the smaller the company's financial distress will be. Therefore, government as a regulator must continuously improve control of corruption so that companies in Indonesia do not experience financial distress that can lead to bankruptcy and can disrupt the economy. The existence of such institutions as the Corruption Eradication Commission (KPK) is certainly a positive thing to reduce corruption. But of course the precautions are always better than cure. However, because corruption is committed by two parties, it is better for the government to have a by-system mechanism in carrying out its activities so that it can reduce the direct interconnection of the two parties which opens the space for corruption.

For companies in IMP sectoral group, high corporate debt will lead to increase financial distress. Therefore, the companies should do a conservative financial management with no debt larger than the company's own capital. Moreover, there is an evidence that the company's ability to generate high profits will reduce the company's financial distress. In addition, the company should increase the number of independent commissioners in order to be able to reduce the company's financial distress.

\section{CONCLUSION AND SUGGESTIONS}

\section{Conclusion}

Financial distress is the inability of a company to pay its obligations. If it is not anticipated, then it could lead to bankruptcies whose social impact could be greater. In all observed sectors (IMP, BCM, \& AT), control of corruption has a negative effect on 
the company's financial distress. It shows that for a developing country like Indonesia, this variable is still a determinant for financial distress problems experienced by companies. Therefore, cooperation from both the government and the bureaucrat is needed to eliminate the possibility of corruption.

Companies in Indonesia have a greater number of independent commissioners than required by the government. The condition indicates that companies in Indonesia, on average, have applied good corporate governance to their control function by involving independent commissioners who come from the outside companies as ruled in the existing regulations.

In addition to control of corruption, in the IMP sector, independent commissioner, size, and profitability negatively affect the company's finan- cial distress, while leverage has a positive effect. On the other hand, in the sector of AT the operational risk positively affects the financial distress of companies.

\section{Suggestions}

Further research using survival analysis still can be conducted especially relating to the sectors of financial and insurance. Moreover, research can also be done in small, medium, and large enterprises, as well as on state-owned enterprises.

\section{ACKNOWLEDGMENT}

This paper is one of the outputs of the Fundamental Grants of the Directorate General of Higher Education (Dikti) of 2017 funding

\section{REFERENCES}

Abdullah, S. N. (2006). Board structure and ownership in Malaysia: The case of distresses listed companies. Corporate Governance, 6(5), 582-594.

Ahmad, G. N. (2013). Analysis of financial distress in Indonesian Stock Exchange. Review of Integrative Business E Economics Research, 2(2), 521-533.

Antikasari, T. W., \& Djuminah. (2017). Memprediksi financial distress dengan binary logit regression perusahaan telekomunikasi. Jurnal Keuangan dan Perbankan, 21(2), 265-275.

Altman, E. I. (1968). Financial ratios, discriminant analysis, and the prediction of corporate bankruptcy. Journal of Finance, 23(4), 589-609.

Andrade, E. I., \& Kaplan, S. (1998). How costly is financial (not economic) distress? Evidence from highly leveraged transactions that became distress. The Journal of Finance, 53(5), 11431493.

Ball, R., Foster, G., Gonedes, N. J., \& Jensen, M. C. (1982). Corporate financial reporting: A methodological review of empirical research/ discussion/ reply. Journal of Accounting Research, 20, 161-248.

Beaver, W. H. (1966). Financial ratio as predictor of failure, empirical research in accounting: Selected studies. Journal of Accounting Research, 5, 71-111.

Becht, M., Bolton, P., \& Roell, A. A. (2002). Corporate governance and control. Finance working paper, 2.

Bhattacharjee, A., \& Han, J. (2014). Financial distress of Chinese firms: Microeconomic, macroeconomic, and institutional in- fluences. China Economic Review, 30, 244-262.

Bhattacharjee, A., Higgson, C., Holly, S., \& Kattuman, P. (2004). Macroeconomic condition and business exit: Determinant of failure and acquisition of UK firms. Working Paper.

Cashman, G. D., Harrison, D. M., \& Sheng, H. (2014). Political risk and the cost of capital in AsiaPacific property markets. Working Paper.

Chancharat, N. (2008). An empirical analysis of financially distress Australian companies: The application of survival analysis. Thesis. School of Accounting and Finance University of Wollongong.

Claessens, S., \& Yurtoglu, B. B. (2013). Corporate governance in emerging markets: A survey. Emerging Markets Review, 15, 133. 
Donato, F., \& Nieddu, L. (2014). A quantitative analysis of trigger factors influencing companies failure in Italy. European Scientific Journal, 10(10), 1-16.

Elloumi, F., \& Gueyie, J. P. (2001). Financial distress and corporate governance: An empirical analysis. Corporate Governance, $1(1), 15-23$.

Fich, E., \& Slezak, S. (2008). Can corporate governance save distressed firms from bankruptcy? An empirical analysis. Review of Quantitative Finance \& Accounting, 30(2), 225-251.

Fisher, C. D. (1993). Boredom at work: A neglected concept. Human Relations, 46, 395-417.

General Guidelines of Good Corporate Governance. (2006). Indonesia the national committee on governance, http://www.ecgi.org/ codes/documents/indonesia cg_2006_id.pdf.

Gepp, A. \& Kumar, K. (2008). The role of survival analysis in financial distress prediction. International Research Journal of Finance and Economics, 16, 13-34.

Glaeser, E. L. (2012). The political risk of fighting market failure: Subversion, populism, and the government sponsored enterprises. Working Paper.

Haendel, D. (1979). Foreign investments and the management of political risk. Westview Special Studies in International Economics and Business.

ICRG. (2016). http:// www.prsgroup. com/ICRG_Methodology.

Keputusan Menteri Badan Usaha Milik Negara No: KEP-117/MMBU/2002 Tentang Penerapan
Praktek Good Corporate Governance pada Badan Usaha Milik Negara (BUMN)

Kleinbaum, D. G. \& Klein, M. (2012). Survival analysis: A self-learning text. Third Edition. New York: Springer.

Kristanti, F. T. (2014). Prediksi kebangkrutan bank-bank yang terdaftar di Bursa Efek Indonesia. Jurnal Keuangan dan Perbankan, 18(1), 130-138.

Kristanti, F. T. (2015). The test of gender diversity and financial structure to the cost of financial distress: Evidence from Indonesian family business. Proceeding GTAR-2015, 2, 554-565.

Kristanti, F. T., \& Effendy, N. (2017). A survival analysis of Indonesian distressed company using Cox Hazard Model. Int. Journal of Economics and Management, 11(S1), 155-167.

Kristanti, F. T., \& Herwany, A. (2017). Corporate governance, financial ratios, political risk, and financial distress: A survival analysis. Accounting and Finance Review, 2(2), 26-34.

Kristanti, F. T., Effendi, N., Herwany, A., \& Febrian, E. (2016). Does corporate governance affect the financial distress of Indonesian company? A survival analysis using cox hazard model with time-dependent covariates. $A d-$ vanced Science Letters, 22(12), 4326-4329.

Laitinen, E. K. (2005). Survival analysis and financial distress prediction: Finish evidence. Review of Accounting \& Finance, 4(4), 7690.

LeClere, M. J. (2000). The occurrence and timing of events: Survival analysis applied to the study of financial distress. Journal of Accounting Literature, 19, 158189.

LeClere, M. J. (2005). Time-dependent and time-invariant covariates within a proportional hazard models: A financial distress applications. Review of Accounting and Finance, 4(4), 91-109.

Ohlson, H. (1980). Financial ratios and the probabilistic prediction of bankruptcy. Journal of Accounting Research, 18(1), 109-130.

Opler, T. C., \& Titman, S. (1994). Financial distress and corporate performance. The Journal of Finance, 49(3), 1015-1040.

Nikitin, G. (2003). Plant failure and survival in the Indonesian financial distress. Working Paper.

Parker, S., Peters, G. F., \& Turetsky, H. (2011). Corporate governance and corporate failure: A survival analysis. Corporate Governance, 2(2), 4-12.

Platt, H. D., \& Platt, M. B. (2002). Predicting corporate financial distress: Reflections on choicebased sample bias. Journal Economics and Finance, 26(2), 184199.

Polsiri, P., \& Sookhanaphibarn, K. (2009). Corporate distress prediction models using governance and financial variables: Evidence from Thai Listed firms during the East Asian economic crisis. Journal of Economics and Management, 5(2), 273-304.

Pujiastuti, T., \& Yuharningsih. (2014). Anteseden probabilitas financial distress pada perusahaan manufaktur di Indonesia. Jurnal Keuangan dan Perbankan, 18, 113. 
Sandstrom, A. (2008). Political risk in credit evaluation-empirical studies and survey results. Dissertation. Swedish Scholl of Economic and Business Administration Helsinki.

Shumway, T. (2001). Forecasting bankruptcy more accurately: A simple hazard model. The Journal of Business, 74(1), 101-124.

Tinoco, M. H., \& Wilson, N. (2013). Financial distress and bankruptcy prediction among listed companies using accounting, market, and macroeconomic variables. International Review of Financial Analysis, 30, 394-419.

Turetsky, S., \& McEwen, R. A. (2001). An empirical investigations of firm longevity: A model of the ex ante predictors of financial distress. Review of Quantitative Finance and Accounting, 16(4), 323-343.

Van-Wyk, J., Dahmer, W., \& Custy, M. C. (2004). Risk management and the business environment in South Africa. Long Range Planning, 37, 259-276.

Voelker, C., Permana, A., Sachs, T., \& Tiong, R. (2008). Political risk perception in Indonesian power projects. Journal of Financial Management of Property and Construction, 13(1), 18-34.

Whitaker, R. B. (1999). The early stages of financial distress. Journal of
Economics and Finance, 23(2), 123-133.

Wruck, K. H. (1990). Financial distress, reorganization, and organizational efficiency. Journal of Financial Economics, 27, 419-444.

Xia-Li, H., Jun-Wang, Z., \& Ian-Deng, X. (2008). Ownership, independent directors, agency cost, and financial distress: Evidence from Chinese listed companies. Corporate Governance, 8(5), 622636.

Zhou, Y., Kim, M. H., \& Ma, S. (2012). Survive or doe? An empirical study on Chinese ST firms. Research Online. University of Wollongong Australia. 